Western University Scholarship@Western

1993

\title{
Hawtrey, Harvard, and the Origins of the Chicago Tradition
}

David Laidler

Follow this and additional works at: https://ir.lib.uwo.ca/economicsresrpt

Part of the Economics Commons

Citation of this paper:

Laidler, David. "Hawtrey, Harvard, and the Origins of the Chicago Tradition." Department of Economics Research Reports, 9302. London, ON: Department of Economics, University of Western Ontario (1993). 


\section{RESEARCH REPORT 9302}

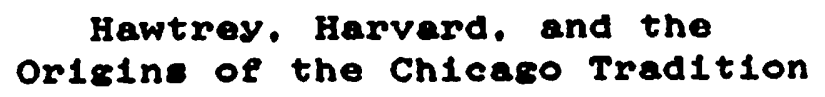

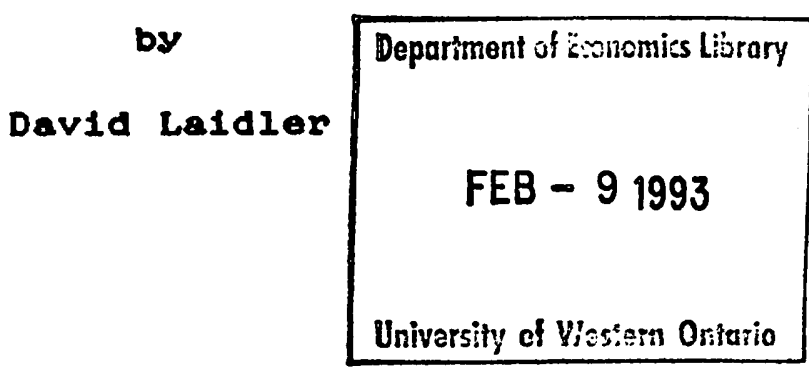

January 1993

Department of Economica

Social science Centre

Univereity of Weatern Ontario

London, Ontar10, Canada

N6A $5 C 2$ 
Revised Version

January 1993

HAWTREY, HARVARD, AND THE ORIGINS OF THE CHICAGO TRADITION

by

\section{DAVID LAIDLER}

This paper forms part of a larger study being carried out with the financial support of the Lynde and Harry Bradley Foundation. I am grateful to Lauchlin Currie for helpful correspondence, to Milton Friedman for comments, and for providing me with a copy of the unpublished Chicago mimeograph on "Banking and Currency Reform" (Simons et. al. 1933), to which extensive reference is made below, and to Mark Blaug, Charles Blitch, Bernard Corry, Sue Howson, Peter Howitt, Mary Morgan, Don Patinkin, Roger Sandilands, Anna Schwartz, and Frank Steindl for helpful comments on an earlier draft. Mr. Toni Gravelle has provided invaluable research and bibliographic assistance. The usual disclaimers apply. 


\section{INTRODUCTION}

The existence of a "Chicago Tradition" in monetary economics was first brought to general attention by Milton Friedman (1956), when he claimed that his version of the quantity theory of money derived from a doctrine which had been under continuous development at the University of Chicago since the 1930s. While not denying the existence of an oral tradition in monetary economics at that institution in the 1930s and 1940s, Patinkin (1969) showed beyond any reasonable doubt, that whatever its contents might have been, the notion that the quantity theory of money was primarily a theory of the demand for money was not among them. Friedman (1974) subsequently conceded the accuracy of Patinkin's suggestion that his model of the demand for money owed little to Henry Simons or Lloyd Mints, but went on to describe an analytic tradition at Chicago which had offered: a monetary explanation of economic fluctuations, and in particular of the Great Depression of 1929-33, as well as an essentially optimistic assessment of the power of monetary policy to deal with that Depression; and in (1967) he had already drawn attention to Henry Simons' advocacy of governing monetary policy by legislated rules rather than the discretion of politicians and central bankers, though he noted that Simons had favoured a price-stability rather than a money growth rule.

Thomas Humphrey (1971) documented the appearance of ideas closely related to this Chicago tradition in the writings of such non-Chicagoans as Carl Snyder (e.g., 1924), Lauchlin Currie (e.g., 1934b), and later Clark Warburton (e.g., the papers reprinted in (1966), which date from 1945 onwards). His paper, together with Patinkin's (1973) comment on it, left the overall impression that the Chicago tradition was less the product of a single department than it was a manifestation of a widely influential and essentially Fisherian approach to monetary economics. ${ }^{1}$ This paper proposes a rather different account of the matter. Specifically, and without denying the existence of a pervasive Fisherian influence, it argues that two of the three distinctive characteristics which Friedman has attributed to 1930s Chicago monetary economics 
also distinguish the analysis of such Harvard economists as Allyn Young and Lauchlin Currie from the broader tradition of American quantity theoretic analysis. It argues further that those characteristics mark the writings of the British economist Ralph Hawtrey, who, from 1913 onwards, developed a monetary theory of the cycle which provided a far richer description of the phenomenon as a "dance of the dollar" than Fisher ever produced. ${ }^{2}$ Even though the work of Young and Currie was systematically empirical, and clearly influenced by the American Institutionalist tradition in which Young had been trained at Wisconsin, and to that extent differed from Hawtrey's, the theory which underlay it was, as we shall see, close indeed to his. And this paper not only demonstrates the presence of similar theoretical ideas in the writings of Hawtrey, these Harvard economists and the originators of the Chicago tradition, but also provides evidence that the people concerned were aware of, and took particularly seriously, the work to which influence is attributed.

It will be shown in the following pages that the monetary interpretation of the Great Depression, which we nowadays associate with Friedman, but which, as Sandilands (1990) and Steindl (1991) have shown, Currie $(1932,1934 a, 1934 b)$ undoubtedly pioneered, was the natural outcome of applying to that specific episode ideas that appeared first in Hawtrey's Good and Bad Trade (1913) and were then developed in Currency and Credit (1919), a book which played an important part in an oral tradition, recognized as such by contemporaries, developed at Harvard by Young; that Hawtrey himself analysed the Depression in similar terms, though by no means as systematically as did Currie; that optimism about the power of monetary policy also marked the work of Hawtrey, Young and Currie, but arrived rather late in the day in Chicago; and that, with due recognition of the priority of Soddy (1926), proposals to establish a regime of what Fisher (1935) was to call 100 per cent money, (ie. to subject chequable deposits to 100 per cent reserve requirements of high powered money) were developed independently by 
both Simons et al. (1933), and Currie (1934b) as responses to the phenomena which Hawtrey had labelled the "inherent instability of credit." ${ }^{\text {3 }}$ At this last point, however, we encounter a fundamental difference between Harvard and Chicago. Whereas Currie's intention was to render activist monetary policy a more useful component of a generally interventionist policy regime, Simons' aim was to make adherence to a monetary rule a more effective feature of a competitive economic order. Thus, the distinguishing feature of Chicago quantity theoretic analysis was normative, namely to link that analysis to a liberal political agenda.

To interpret the positive theoretical content of the "Chicago Tradition" as being essentially the same as that of the work of Hawtrey and certain Harvard economists, is also to suggest that it has the same origins as much of the macroeconomics of the New Deal. That is perhaps one reason why the "Monetarism" which emanated from Chicago in the mid 1950s has turned out, upon closer and more dispassionate inspection than it was originally accorded, to have, from an analytic point of view, a good deal more than a capital theoretic approach to modelling the demand for money in common with the American "Keynesian" orthodoxy to which it was opposed.

\section{HAWTREY'S ANALYSIS}

Much evidence to support the story just outlined is already in the secondary literature. For example, there is no doubt that Hawtrey's work attracted widespread attention during the 1920s and early 1930s. Haberler's (1937) authoritative survey of business cycle literature presents Hawtrey as the leading exponent of a purely monetary theory of the trade cycle, and, as Deutscher (1990) has told us, before the publication of the General Theory he was cited with impressive frequency in the journal literature on macroeconomics -- indeed with the same frequency as Fisher over the 1931-1935 period. As to the visibility of his work in the United States, Deutscher has also documented the attention paid to it by Allyn Young, who was 
instrumental in arranging Hawtrey's only academic appointment, as a visitor at Harvard during 1928-29. Joseph Schumpeter, would later $(1954$, p. 1121) note the frequent references made to Hawtrey's analysis by defenders of Federal Reserve policy as it was conducted before 1928 . Moreover, Currie's anticipation of what would come to be called the "monetarist" interpretation of the Great Depression, has already been noted by Karl Brunner (1968), Humphrey (1971), Patinkin (1973), Sandilands (1990) and Steindl (1991); and Currie was Hawtrey's assistant at Harvard in 1928-29. He would have been Young's assistant too, had it not been for the latter's untimely death in $1929 .^{4}$

As I argued in Laidler (1991), among the leading pre-World-War-I exponents of the quantity theory of money, only Fisher offered a purely monetary explanation of the cycle. Hawtrey's pre-war work on the topic, as it appeared in his Good and Bad Trade (1913), drew explicitly on the Fisherian tradition -- Fisher (1911) was the only work he cited there -- but much of its detail was of recognisably Marshallian origin. Though Hawtrey should not be characterised as a quantity theorist as the term would have been understood by his contemporaries, his work certainly falls within a monetary tradition of business cycle analysis that built upon the quantity theory. 5 The distinctive variations upon that tradition which Hawtrey developed in Good and Bad Trade were to remain central features of his post-war work and differentiate it rather sharply from Fisher's. In particular, where Fisher had written The Purchasing Power of Money primarily about the secular relationship between money and prices, and had discussed the cycle in only one chapter dealing with "Transition Periods," the whole of Good and Bad Trade was about the cycle, and Hawtrey's next work Currency and Credit (1919) retained this emphasis. Young remarked explicitly on this characteristic in his review of its first edition: - ". . Mr. Hawtrey is less interested in imagined states of monetary equilibrium than in what Professor Irving Fisher would call transition periods. . ." (1919-20, p. 
525) -- as he did also in a subsequent review of its second 1923 edition. $^{6}$

Hawtrey's attitude to the quantity theory, in the sense of an hypothesis about a long run proportional relationship between money and the general price level, was expressed succinctly in the Preface to Currency and Credit

"Scientific treatment of the subject of currency is impossible without some form of the quantity theory. . .But the quantity theory itself is inadequate, and it leads up to the method of treatment based on what I have called the consumers' income and the consumers' outlay - that is to say, simply the aggregates of individual incomes and individual expenditures." (1919, p. v)

And this early version of an income-expenditure approach was by no means Hawtrey's only departure from a more conventional Fisherian approach. In 1919, the word "money" usually referred to "currency," and that indeed is how Hawtrey then used it; but he regarded "credit," by which he meant, as Currie (1934b p. 48) was later to stress, chequable demand deposits, as playing a far more important role in the financial system, so much so that he actually began Currency and Credit with an analysis of a simplified monetary system from which currency was totally absent. ${ }^{7}$ This is exactly the opposite simplification to that adopted by Fisher at the beginning of the Purchasing Power of Money, where an economy using only currency is the first considered, and its purpose was to enable Hawtrey to develop from the outset, and in a clear-cut fashion, an hypothesis that was always utterly central to his work, namely "the inherent instability of credit": the hypothesis that any shock to the system which disturbed bank lending, and therefore the volume of deposits, particularly in an upward direction, would tend to generate a perpetual and perhaps accelerating movement.

In the case of contraction, falling interest rates induced by ".. the self interest of the bankers and the distress of the merchants combine to restore the creation of credits. . .[b]ut in the case of the expansion of credits there is no such corrective influence a work." $(1919$, p. 13) This cumulative process of credit expansion has about it a strong flavour of Wicksell's (1898) 
"pure credit economy" (see Laidler (1991, Ch. 5), though there is no evidence that, in 1919, Hawtrey was aware of this work. Two important elements in the mechanism driving it, however, have no parallel in Wicksell. The first involved the inventory holding decisions of wholesale merchants: in the face of expanding demand not immediately matched by an increase in short term interest rates, they would seek to increase, or at least maintain, the levels of those inventories with the aid of loans from the banks. The second, closely related, involved the way in which the deposits created in this process would swell the economy's "unspent margins" (money holdings, in modern terminology) beyond the levels desired by agents, and hence induce increased expenditure which would in turn frustrate wholesalers' plans for inventory accumulation. In the absence of currency, this process could continue for ever, but in fact currency's dual role as a reserve for the banks, and an alternative means of exchange to deposits for the public, placed a limit on it. In Hawtrey's words, ". . .money [i.e., currency]. . .has to correct the instability of credit." (1919, p. 15) An expansion of money incomes and expenditures would lead to a drain of currency from the banks, and induce them to increase the nominal interest rate sufficiently to bring to an end, and indeed to reverse, the upward cumulative process.

In Hawtrey's view, two factors in particular made a reversal virtually inevitable. First, during the boom, expenditures would rise, not in proportion to money creation, but in greater proportion because the rate of increase, as well as the level, of deposits would have a positive effect on consumers' expenditures (cf. 1919 pp. 38-46); and second, the demand for currency relative to deposits in the make-up of the public's "unspent margins" would depend upon the distribution of national income between wages and profits. ${ }^{8}$

". . it is only after a considerable interval that the prosperity of the manufacturers is reflected in an increase in wages. Consequently it is only very gradually that the bankers can become aware that the growth of credit is threatening their reserves of coin." $(1919$, p. 23) 
And the stickiness of wages posited here, because it operated in a downward as well as an upward direction, had a further consequence: namely fluctuations in employment as an inherent characteristic of the cycle.

"The alternative of expansions and contractions would be comparatively harmless but for the dislocation and distress which accompany the contraction. . . The working classes have the greatest interest in the stable currency, and. . the question of justice between debtor and creditor is less important than the effect of currency movements on employment and real wages." (1919, pp. 375-376)

Hawtrey conceded that what amounted to a competitive banking system did have it within its powers to stabilise the cycle:

"If the bankers keep large reserves and take early steps to safeguard them, not merely when the proportion of reserve to liabilities falls below their conventional limit, but as soon as trade begins to become suspiciously profitable, and if they have the courage to avoid panic measures even when their reserves seem to be melting away to nothing, they are likely to keep control of the situation. But bankers are human. . ." $(1919$, p. 28)

Hence, as a practical matter, if the inherent instability of credit was to be counteracted, and the cycle mitigated, a central bank was required. Even the operation of an international gold standard with variations in the supply of currency linked rigidly to variations in gold reserves (as they were under the 1844 Bank Charter Act which had regulated the Bank of England's behaviour until 1914) did not change this. In a monetary system dominated by deposit banking, "The note-issuing authority which regulates the supply of legal tender paper money is really dependent upon the control of credit for passing the notes into circulation." $(1919, \mathrm{p} .49)$ And "[i]n fact, experience has shown that even with an automatically regulated paper currency, which does not need to be managed on banking principles, a central bank for the control of credit is almost indispensable. For a long time the United States was an example, or rather a warning, of the contrary system." (1919, pp. 78-79)

Now Hawtrey's best known contribution to specific matters of policy involved the Genoa Conference of 1922, and the resolutions (never acted upon) that emanated from it concerning the desirability of co-operation among central banks to ensure that their efforts at restoring and maintaining stability in domestic monetary systems were compatible with the restoration and 
maintenance of an international gold standard in the wake of its disruption by the First World War. But more important in the context of this paper is his knowledge of United States' experience, and the above comment on the workings of the National Banking system is no mere isolated remark. Hawtrey was a well informed observer of the United States' monetary system. The analysis first set out in Good and Bad Trade had treated open economy considerations as peripheral to cyclical mechanisms, and even though from Currency and Credit onwards Hawtrey paid more attention to international factors, this analysis remained at the heart of all his later work on the cycle. As he subsequently (1962) pointed out, Good and Bad Trade was a response, not to any specifically British experience, but to the depression which followed the United States' crisis of 1907, which among other effects, had helped provoke the establishment of the Federal Reserve System. It is no surprise, then, that Hawtrey's analysis proved readily applicable to, and provided the basis for, much commentary on the System's operations in the 1920s and early 1930s; and, indeed, a wide range of issues which were to be become important in subsequent American discussion had been broached in his work by 1919.

For example, Hawtrey had already argued in the first edition of Currency and Credit that, though stock market speculation was usually a feature of the boom phase of the cycle, and that in ".. .the more usual sequence of events. . .[a] serious fall in the prices of securities will precede the crisis itself. .." (1919, p. 141), it was important not to attach too much significance to this point:

"Speculators in stocks are so especially exposed to the strain of a crisis, that particular crises are very commonly explained as due to 'overspeculation'. In point of fact, however, there are examples of periods of furious speculation which led to no crisis at all." (1919, p. 147)

This was later to be his position, and that of others, notably Currie (1934a \& b) with respect to the particular events of 1929.9 Currency and Credit also contains an early and undogmatic discussion of another matter much debated in subsequent years, namely the relative desirability 
of aiming monetary policy at stabilising prices or money wages. This discussion was mainly directed towards questions of fairness between debtors and creditors, and concluded that "[e]ither view seems to be perfectly tenable, and neither seems necessarily to represent the last word of justice." (1919, p 375) For Hawtrey, this question was ". . less important than the effects of currency movements on employment and real wages" (1919, p. 376, italics added).

Hawtrey also told his readers in 1919 that commercial banking ". . comprises two distinct functions -- temporary lending, and the provision of transferable credits as means of payment. Their union is a matter of convenience and not of necessity." $(1919$, p. 378) He thus stated one basic premise of the case subsequently made for "100 per cent money," though he did not, of course, go on to make that case. On the contrary, he argued that to separate these functions so that ". . the supply of purchasing power would lose its elasticity" (1919, p. 378) would not put a stop to merchants economising on cash by obtaining credit by other means. For Hawtrey, indeed,

"Far from causing the cyclical fluctuations, a banking system diminishes their violence and facilitates their control. Nevertheless, though credit institutions are not themselves the cause of this phenomenon, yet where such institutions exist it is through them that the fluctuations take effect. It is these credit movements which determine the "rapidity of circulation" of money and of credit. There is no need to dwell on the futility of any theory of currency which accepts the 'rapidity of circulation' or the 'needs of trade' as something given, something determined from outside independently of the currency system itself." (1919, p. 379)

As we shall see, these issues raised by Hawtrey in 1919 - the variability of the currency-deposit ratio as a crucial characteristic of the cycle, the debatable role of stock-market speculation and its collapse in foreshadowing a cyclical downturn, the question of tying monetary policy to a rule, and if so which, the possibility of divorcing the provision of means of payment from the granting of short term credit, and the dangers of treating the "needs of trade" as independent of the behaviour of the monetary system, the basis of what is now known as the "real bills," doctrine -- all played prominent roles in the subsequent monetary debates in the 
United States. As we shall also see, Hawtrey's undogmatic skepticism about the need for rules or radical reforms, something surely to be expected from one who regarded central banking as an "Art", found more sympathy among Harvard economists than those at Chicago; but this does not alter the fact that, in both places, the agenda for discussion was dominated by questions that he had raised as early as $1919 .^{10}$ Many of these issues had of course been raised by others, at about the same time. It is not claimed that Hawtrey invented the agenda for monetary debates in the 1920s and early 1930s. But it is nevertheless the case that the comprehensiveness of Currency and Credit made it unique among English language works of the early 1920s as a statement of that agenda. In his review of its second edition Allyn Young (1924) called it "...one of the most significant -- possibly the most significant of modern treatises on money" (1924, p. 349, italics in original), and it was on reading lists at Harvard, his and then Currie's, throughout the 1920s and early 1930s.

\section{ALLYN YOUNG, LAUCHLIN CURRIE, AND THE HARVARD TRADITION}

Harvard's reputation in monetary economics in the years immediately preceding the arrival of Keynesian ideas is one of mediocrity; and even allowing for the tendency to disparage anything thought, said, or written before 1936 which accompanied the Keynesian Revolution, that reputation is not altogether undeserved. ${ }^{11}$ Anyone who doubts this is invited to peruse the 1934 commentaries on The Economics of the Recovery Program (Brown et. al. 1934) prepared by members of the department, most of which verge on the incoherent and do no credit to their distinguished authors. ${ }^{12}$ But, until as late as 1934 , outstanding work in the quantity theoretic tradition was done at Harvard, the best of it at least as good as anything that would emanate from Chicago in the 1930s, and indeed, if careful empirical analysis is valued, far better.

Most of this work was due to Allyn Young and Lauchlin Currie, though

John $\mathrm{H}$. Williams made at least one noteworthy contribution as a transmitter of ideas, as we 
shall see below. The fact that this work is not well known nowadays is mainly due to a series of unfortunate events which cut short its progress. First, Young died early in 1929 at the age of 52 , in the penultimate year of what he had intended to be a temporary appointment at the London School of Economics. Second, Currie was a graduate student and then an instructor at Harvard, but never a tenured member of the faculty; and, having been selected by Jacob Viner to join the Roosevelt Administration's "freshman brains trust" he was refused leave by Harvard to extend his stay in Washington beyond the summer of 1934, thus forcing his resignation. His subsequent career in Washington, as Sandilands (1990) shows, gives him a strong claim to be considered as a major intellectual force in the development of the macroeconomic policies of "The New Deal", but he also became distanced from the academic community. In the post-war years, his difficulties with the House of Representatives Un-American Activities Committee, documented by Sandilands (1990), made a return to academic life in the United States impossible.

To complicate matters further, more monetary analysis seems to have been discussed and taught at Harvard than found its way into print. Currie tells readers of his (1934b) book that "Most of the subject matter. . has been taught in the first half of the money and banking courses at Harvard for some years" (1934b, p. ix), courses which Currie taught as an assistant to Williams who also acted as his Ph.D. supervisor, and there is also a book that did not get written. Young had projected a treatise on monetary economics which presumably would have provided a systematic written account of ideas which, according to Oscar Morgenstern (1929) had ". . become at Harvard a matter of oral tradition, just as -- according to Keynes -Marshall's theory of money at Cambridge" (also quoted by Deutscher 1990, p. 196). He was working on it from 1927 onwards, but whatever he had completed was lost, presumably destroyed, when his office at the London School of Economics was cleared out after his death. ${ }^{13}$ 
But though Young left no systematic exposition of monetary economics, he nevertheless published enough work on monetary issues for us to be able to get a flavour of his thought. He was, as we have seen, a great admirer of Hawtrey, but he was far too individual a thinker simply to adopt and repeat Hawtrey's views, or those of anyone else, for that matter. Thus the chapter on "Business Cycles" which he prepared for the 1923 edition of Richard Ely's widely used textbook Outlines of Economics refers its readers to Good and Bad Trade (which Young thought easier reading than Currency and Credit -- see 1919-20, p. 521). But Robertson's Industrial Fluctuations (1915) is also recommended, and Young pays more attention to fixed investment than did Hawtrey. Hawtrey's emphasis on the role of traders was not, in fact, to be a feature of subsequent Harvard or Chicago work on the cycle and, indeed, we know from Nicholas Kaldor's notes on his 1927-29 LSE lectures that Young regarded this element as overemphasised in Hawtrey's analysis. (See Sandilands (ed.) 1990 pp. 82-83.) Young is altogether more eclectic than Hawtrey in his views on the sources of economic instability, mentioning ". . .maladjustments, born in part of the redistribution of incomes. .." not to mention ". . .crop failures, or crises in other countries. . ." as factors in addition to ". . the exhaustion of bank reserves. . ." likely to bring a cyclical upswing to an end. (See 1923, p. 335). And he also makes a case for public works expenditure as a counter-cyclical device, a position quite contrary to that taken by Hawtrey in the 1920 s.

Nevertheless, the role of the banking system in the cycle gets more emphasis in the (1923) edition of the Outlines... than in its (1916) predecessor, which does not contain a separate chapter on the cycle; and though the capacity of the newly established Federal Reserve System to use its rediscounting mechanism, and open market operations, to render cyclical fluctuations ". . less frequent and less violent than in the past" was recognised in this earlier edition (See 1916, p. 311), discussion of the ". . proposal. . that the control of the volume of 
bank credit be used as the means of controlling the fluctuations of the business cycle" is much more extensive in the later edition. All of this points to Hawtrey's influence, as does the fact that Young there notes that the Bank of England's use of discount policy in earlier years had been designed primarily to protect its gold reserves, rather than to stabilise the cycle. This distinction too is to be found in Hawtrey's work, and leads to important insights about the essential novelty of attempting systematic counter-cyclical monetary policy.

At the beginning of the 1920s, to use Hawtrey's later (1932) words,

". . the authorities in control of the Federal Reserve System deliberately departed from that mechanical subservience to [gold] reserve proportions which had previously been supposed essential to the art of central banking. Under the wise guidance of Governor Benjamin Strong of the New York Bank they pursued a policy of stabilisation, which prevented any serious fluctuations in the price level from 1922 to 1929 . . It was a disaster for the world that Governor Strong died in the autumn of 1928, and the experiment came to an end." (1932, pp. 208-209)

During much of this $1922-28$ period, Young was a consultant to the New York Bank, and he also carried out an extremely careful Analysis of Banking Statistics for the United States, published first in a series of four articles in the Review of Economic Statistics, and then gathered together in a (1928) book of the above title. ${ }^{14}$ The statistics in question appertained to National Banks only, and only the last of the four articles deals with post 1914 data -- 1915-26 to be precise. But they document the pronounced seasonal movements of currency out of New York in the autumn which, when combined with the propensity of New York banks to hold call loans to the financial markets as secondary reserves, did much to contribute to the fragility of the National Banking system; and above all, they document New York's central place in what even before 1914 had become (perhaps with the exception of California) an integrated nationwide monetary system. The work is mainly descriptive, but Young did remark, with respect to the movements of funds into New York banks from the hinterland, and thence through financial markets and out to the hinterland again, and their associated fluctuations in reserve and currency 
deposit ratios, that

"I have little doubt but that the relations such as we are now considering lie at the very heart of the problem on the instability of the modern mechanism of bank credit and those business activities which depend upon credit. The discussion of that problem falls outside the limits set for the present volume." (1928, p. 28)

And to this aside he appended a footnote: "I know of no better analysis of the essential instability of the volume of bank credit than is to be found in R.G. Hawtrey's work, Currency and Credit." (1928, p. 28, fn. 1$)^{15}$

One other work of Young's deserves our attention, an essay, evidently written for lay readers, which first appeared in two parts in a weekly called The Annalist and was reprinted as chapter 5 of his collection Economic Problems New and Old (1927) on "The Structure and Policies of the Federal Reserve System." Young begins by noting that

"The fundamental principle of central banking is very simple. It is merely that there should be a bank or group of banks set apart from ordinary commercial banks by the circumstance that their policies are shaped with an eye not merely to their own profits and their own solvency, but to the continued solvency of the banking system of the country taken as a whole." (1927, pp. 77-78)

But he extends this essentially Bagehotian proposition by also pointing out that

"Since the war new importance has been attached to the effects which the operations of central banks have on the general conditions of business, and it is quite generally held that their policies should be determined with primary reference to the securing of the maximum practicable degree of business stability." (1927, p. 80)

He also stresses the importance of ". . that practical wisdom which is born only of experience" in enabling the Federal Reserve Banks to fulfill their task, and is quite explicit that "A sound tradition would not be the kind of thing which could be formulated in a set of rules and maxims" (1927, p. 82), thus echoing the position taken in the previous year by Governor Strong in opposing legislation that would have established the single minded pursuit of price level stability as a rule for Federal Reserve policy. ${ }^{16}$

This essay also states the policy implications of Young's above-mentioned work on 
United States Banking Statistics. Its second half is devoted to arguing that

"Those who planned the Federal Reserve System confidently expected that the system would operate so as to do away with the 'artificial' concentration of banking power in New York.

These expectations were bound to be disappointed, for they were based upon a mistaken analysis of the situation that existed in the United States before the Federal Reserve System was installed, and upon a failure to take into account some very important aspects of the operations of central banks in other countries." (1927, p. 84)

Two features of the United States system were particularly important here, namely the fact that "New York still retains its unique position as the centre in which the surplus banking funds of the country are concentrated" $(1927$, p. 89$)$ and the fact that New York is ". . our only really important point of contact between the domestic and international money markets." (1927, p. 90) For Young, these facts inevitably meant that "The New York Bank has come to have a position of primacy in the Federal Reserve System merely because it has not tried to shun the responsibilities which are naturally assigned to it by the structure of the national money market. . ." (1927, p. 92); and they suggested to him the wisdom of

". . frankly conceding larger responsibilities and larger powers to the New York Bank. . . [rather] than to run the danger of 'unifying' the system into a cumbrous and slow-moving substitute for a single central bank, with divided authority and divided responsibilities." (1927, p. 94)

The warning implicit here was prophetic: conflict between the New York Bank and the Federal Reserve Board about their respective powers and responsibilities was already evident in 1927, and would be a major contributor to the ineptitude with which monetary policy was conducted after what Hawtrey termed the "disaster" of Benjamin Strong's death.

Young too died before his warnings materialised, but the analysis from which they derived continued to be developed, particularly by Lauchlin Currie, whose work has, as I have already noted, been the subject of commentaries by Brunner (1968), Humphrey (1972), Patinkin (1973), Sandilands (1990) and Steindl (1991). Readers of the above-mentioned commentaries 
will be aware that Currie was a graduate student and then a junior faculty member at Harvard from 1926 until 1934, that he submitted a Ph.D. thesis (Currie 1931a), entitled Bank Assets and Banking Theory in 1931, and in the next few years wrote and published extensively on matters of monetary theory and policy, gathering the main results of his work in a monograph The Supply and Control of Money in the United States (1934b).

Though Currie's book was not a reworking of his thesis, it did contain some material taken from this earlier work, notably a thorough discussion of "The Meaning of Credit" which supplemented a vigorous critique of what Lloyd Mints (1945) would later call the "real bills doctrine," but what Currie termed, following the usage of the period, the "Commercial Loan Theory of Banking." An intermediate version of this chapter was published (1933a) in the Journal of Political Economy. Another article (1934a) of Currie's, "The Failure of Monetary Policy to Prevent the Depression of 1929-32," whose substantive message was also incorporated into his monograph, appeared in the same journal in April 1934. And anyone concerned with assigning priorities among exponents of a monetary interpretation of the Great Depression should note that an outline of Currie's views was published as early as 1931, in a book review in the American Economic Review (Currie 1931b). The dangers of confusing money and credit, the role of that confusion in permitting a monetary contraction to begin in 1928 , not to mention the possibility that the subsequent downtum of 1930 was due to that contraction, are all discussed there, as indeed they are in Currie's unpublished dissertation submitted in January of that year.

The influence of Young on Currie's work is pervasive, and his (1934b) monograph is in fact dedicated to Young. By far the greater part of that book's quantitative content documents variations in the public's currency deposit ratio, not to mention the behaviour of excess reserves 
within the banking system, all very much in the spirit and style of Young (1928). But just as Young was no mere exponent of other people's ideas, so Currie too made his own considerable contribution to the tradition in which he was working. Like Hawtrey, whose monetary theory of the cycle had formed the basis of a chapter on "Bank Assets and the Business Cycle" in Currie's (1931a) dissertation, where it was accorded 9 pages (pp. 211-219) of exposition and criticism, Currie was cautious about pushing the quantity theory of money too far, but, also like Hawtrey, he was aware of the dangers of abandoning quantity theoretic analysis altogether: ". . in the past an altogether disproportionate amount of importance was attached to variations in the supply of money. In consequence of the almost universal abandonment of the quantity theory of money, however, there is danger that the pendulum may swing too far in the opposite direction of that the effect of variations in the supply of money may be unduly minimised." (1934b, p. 3)

Hence Currie was particularly critical of Keynes (1930) for placing too much emphasis on interest rate variations in the Treatise. . arguing that his ".. . viewpoint tends. . .to obscure the really important role played by changes in the supply of money" (1934b, p. 5), and "money" in Currie's view was to be defined as ". . those instruments possessed by the public by delivery of which debt contracts and price contracts are discharged." (1934b, p. 11) In the United States, this meant currency in the hands of the public plus demand deposits, and this point is of some importance. A tightening of United States monetary policy in 1928 is much more evident in Currie's data for this aggregate than in the series constructed at the same time by another former student of Young's, James Angell, (See Angell 1933) which included time deposits; and that is surely one reason why Currie was far more definite in attributing the onset of the depression to Federal Reserve policy than was Angell, or indeed Henry Simons, who in (1935) criticised Currie for his allegedly over-narrow definition of money. ${ }^{17}$

Currie, again like Hawtrey, to whose work he explicitly referred on this point (see Currie 1934a, p. $145 \mathrm{fn} .2$ ), believed that ". . the shrinkage of spending power and the Wall Street 
crisis [of October 1929] were both the effects of a common cause,. . .credit contraction. .." (Hawtrey, 1932, p. 80), and he attributed this "credit" (ie. money supply) contraction to the Federal Reserve system's adherence to the "commercial loan" theory of banking, or as Charles O. Hardy (1932, pp. 124-125) whom Currie also cited with approval at this point termed it, the "Washington" view of the matter (as opposed to the "New York" view which Hardy associated in particular with Benjamin Strong). ${ }^{18}$ Currie was, of course a defender of this "New York" view. He saw disagreement as stemming in some measure from semantic confusion: ". . the term [credit] was in the way of acquiring among monetary writers, a fairly precise connotation: means of payment represented by demand deposits." (1934b, p. 48), (he cited both Hawtrey and Young, among other authorities, for this usage), but unfortunately ". . particularly in America, [the term] has become increasingly identified with something else. . .loans of all kinds, and particularly bank loans and investments." (1934b, p. 48) with the result that ".. .much of the monetary theory of the past, built up in connection with the control of money by the central bank, has been misapplied by the banking authorities to loans and investments. .." (1934b, p. 56).

In 1928 , in an effort to check stock-market speculation, the authorities had tried to cut down bank lending for financial transactions, while maintaining its availability to commercial and industrial borrowers. The effort had been a partial success in its own terms, but had led to the reduction in the money supply which in Currie's view, precipitated a downturn in economic activity. Thereafter, according to Currie, the transformation of a downturn into a depression was also largely the responsibility of the Federal Reserve System. Already in (1931a) he had expressed the opinion that "a much greater expansion of credit ought to have been brought about after the downturn in business in 1929 than did in fact take place" (p. 238), and by 1934 he was arguing that 
"Much of the current belief in the powerlessness of the Reserve Banks appears to arise from a complete misreading of the monetary history of 1929-32. It is generally held that the reserve administration strove energetically to bring about expansion throughout the depression but that contraction continued despite its efforts. Actually the reserve administration's policy was one of almost complete passivity and quiescence." (1934b, p. 147)

That the banking system had increased its holdings of excess reserves and stayed away from the discount window, and that the public had begun to hoard currency in increasing amounts during 1930-32 was as well known to Currie as anyone, but this meant to him not that the authorities were powerless, but merely that ". . the initiative must be taken by the reserve banks themselves, through increased purchases of bills and securities." (1934b, p. 103) Though he conceded that open market operations would have been more effective if undertaken promptly, he did not believe, as did most of his contemporaries, that the public's unwillingness to borrow from the banking system had presented an insuperable barrier to their effectiveness. Currie (1934b p. 116) cites Taussig and Mitchell as holding this latter view, but on this point he could have included even Hardy whose criticism of Federal Reserve policy during the depression for being too cautious (1932, pp. 55-60) was nevertheless tempered by considerable skepticism about the effectiveness of monetary policy:

"It would be unjustifiable to impute to the Reserve system primary responsibility either for the prosperity which the country enjoyed during the major portion of the period under review, or for the disasters with which the decade closed." (1932, p. 239)

In a review essay on Keynes' Treatise. . ., John H. Williams (1931), who had become Currie's Ph.D. supervisor as a result of Young's death, had also been skeptical about both the central role of monetary factors in generating cyclical fluctuations, including the then rapidly developing downturn, and the power of monetary policy to deal with it, though by 1932 his position had, as we shall see, changed somewhat. But Hawtrey had expressed considerable faith in the power of monetary policy in general, and open market operations in particular to offset 
the Depression in his (1932) Art of Central Banking, a work with which, as we have seen, Currie was both familiar and sympathetic:

"Obviously, however intense the depression, the unwillingness of borrowers can never be absolute and universal. That would only occur if all economic activity had been completely shut down. To some extent borrowers will come forward. . If the bills offered and the suitable applications for advances are inadequate and do not increase fast enough, the banks have the alternative of buying long-term investments of a suitable marketable character. . . There must ultimately be a limit to the amount of money that the sellers will hold idle, and it follows that by this process the vicious circle of deflation can always be broken, however great the stagnation of business and the reluctance of borrowers may be. (Hawtrey 1932, pp. 173-174)

Though Currie agreed with Hawtrey about this, even in the light of the experience of 1929-32, which ". . .should not be cited as evidence of the inability of a central bank to arrest contraction of money and bring about expansion" (1934b, p. 148, italics in original), he nevertheless believed that a better system of monetary control ". . in which expansions and contractions of the supply of money could be brought about easily and quickly to any required extent" (1934b, p. 151) could be devised. Specifically "It appears to the writer that the most perfect control could be achieved by direct government issue of all money, both notes and deposits subject to check." (1934b, p. 151) Thus Currie was an independent originator of one version of what came to be called "The Chicago Plan" for 100 per cent. money, whose ". . difference from the present system would lie in the substitution of certainty and precision of control for the existing uncertainty and lack of precision." $(1934 \mathrm{~b}, \text { p. } 156)^{19}$

Now it is clear that in the writings of Hawtrey, Young and Currie are to be found many elements of what Friedman (1974) has termed the "Chicago" tradition: a monetary approach to cycle theory which derived from, but went far beyond the Quantity Theory of Money; opposition to the "real bills" doctrine; a belief that the Great Depression was largely the result of inept policies pursued by the Federal Reserve System under the influence of that doctrine; confidence in the effectiveness of properly conceived monetary policies to alleviate the 
depression; and a version of the $100 \%$ money scheme; all are there. As we have also seen, certain of these crucial elements were missing, or explicitly denied, in the works of other influential contemporary economists -- Taussig, Mitchell, and indeed Hardy, to whom Friedman (1974) was later to refer as "a Chicagoan at one remove" -- and Chicago itself in the 1920s was still, to some extent, under the influence of that arch-opponent of the Quantity Theory, J.

Laurence Laughlin. But it is nevertheless the case that some Chicago discussion of these issues began to appear in 1932 and 1933, before much of Currie's work, where these ideas are most fully developed, saw print. The question must arise, therefore, as to whether the Chicago tradition was a simultaneous and independent development, responding to influences other than those described here, or whether it derived from them. And this question is made all the more interesting by the fact that one important element in the Chicago tradition, namely a commitment to governing monetary policy by rules rather than discretion is not merely missing from the writings of Hawtrey, Young and Currie, but rather is considered and explicitly rejected by all three, and by the fact that the systematic and careful empirical analysis of Young and Currie has no parallel in the work of the Chicago economists. ${ }^{20}$

\section{THE CHICAGO SCHOOL}

It is easy to show that, in the early 1930s, Chicago economists were well aware of Currie's work. Two of his most important articles appeared in the Journal of Political Economy in 1933 and 1934; and by the early summer of 1934 Jacob Viner, an editor of that journal, who seems to have first met Currie in 1932, had evidently got to know him well enough, and come to think highly enough of his work, to invite him to Washington as a member of the "freshman brains trust". ${ }^{21}$ There must also have been contact between Currie and his former undergraduate student Albert Hart, who had moved on to Chicago and in 1935 would publish 
the definitive account of the "Chicago Plan" for $100 \%$ money. The published record makes it clear that Hart drew Currie's attention to the now well-known, though never published, Chicago mimeograph dealing with this issue (Simons et al, 1933) sometime between late 1933 when it was prepared, and the autumn of 1934 when Currie's book, containing a similar proposal, appeared (see Currie, 1934b, p. 156, fn. 1). Furthermore, Henry Simons reviewed the book in question in the April 1935 issue of the Journal of Political Economy, and referred to it as expounding". . .a set of views. . firmly established in the oral tradition of some schools" [note the plural] $(1935$, p. 555).

Chicago economists must have been aware of Young's work too. Not only had he been Frank H. Knight's thesis supervisor, and remained his friend and correspondent thereafter, but, more to the point, the 1928 journey shortly after which Young contracted his fatal influenza was between London and Chicago. It had been undertaken partly to attend the American Economic Association meetings in that city, but mainly to decline in person the offer of the chairmanship of the department of economics at the University of Chicago. Is it too much to presume that members of the Chicago department would have taken the trouble to make themselves aware of at least the outlines of the work Young then had in progress? And that work was, by all accounts, on money.

There is also the matter of the Harris Foundation conference on Gold and Monetary Stabilization, held at the University of Chicago early in 1932, out of which came a manifesto, sent by telegram to President Hoover, which, among other things ". . .recommend[ed] that the Federal Reserve banks systematically pursue open market operations with the double aim of facilitating necessary government financing and increasing the liquidity of the banking structure" (Wright ed. 1932, p. 162). The manifesto was, as Friedman (1974, p. 164) points out, signed by twelve University of Chicago economists, and following J. Ronnie Davis (1968), he treats it as 
illustrative of the "intellectual climate at Chicago", though he is careful to observe that the views it expressed were not confined to that Institution. As he notes, it was signed as well by twelve others, from nine institutions ". . .including Irving Fisher of Yale, Alvin Hansen of Minnesota, and John H. Williams of Harvard. .." (1974, p. 164).

But though twelve Chicago economists, including Frank H. Knight, Henry Simons, and Jacob Viner were among the signatories, Paul Douglas was not; and Douglas was later to remark, with explicit reference to the debates of early 1932 in general, and the proceedings of the Harris Foundation conference in particular, that "Those who, like myself, expressed their disbelief that any real stimulation of business would follow [big open market operations], were either laughed aside or regarded as rather loose brained heretics." (1935, p. 117). So the Chicago economists were not unanimous on this matter, after all; and Douglas mentions James H. Rogers, of Yale, rather than any of his colleagues, as being a particularly vigorous advocate of expansionary open-market operations at this 1932 conference. $^{22}$ Nor should it be thought that the manifesto was a product of Chicago thinking, to which certain other conference participants were willing to put their signatures. It was in fact drafted by a committee consisting of Irving Fisher, Alvin Hansen, Charles Hardy, Henry Schultz, Jacob Viner, and John H. Williams, and of this group, it was ". . Professor Williams. . .[who] was asked to contribute [an] article. . .on the practical problems of relieving depression, with special attention to the subject matter of these recommendations" for inclusion in the conference proceedings (Wright ed., 1932 p. x). ${ }^{23}$ Williams, it will be recalled was not merely from Harvard, but had just finished supervising Currie's Ph.D. thesis, and was involved with Currie in teaching monetary economics. $^{24}$

A comparison of Williams' paper with that presented at the same 1932 conference by Viner shows interesting similarities -- but even more interesting differences. Viner and 
Williams were both critical of recent Federal Reserve policy, and both placed much of the blame on the Federal Reserve Board's belief in the "commercial loan" theory of banking. Viner's remarks on this matter (from which Friedman (1974) also quotes) were particularly pithy:

"While the New York Federal Reserve Bank has made more effort than any other central banking institution to develop a program and technique of credit control with a view to stabilization, it has at critical moments found itself at crosspurposes with, and inhibited from action by, a Federal Reserve Board with an attitude towards its functions resembling with almost miraculous closeness that of the Bank of England during its worst period. (1932, pp. 37-38)

Viner and Williams were both unenthusiastic about the gold standard, not only as a general framework for organising monetary systems, but also because, in 1932, adherence to it inhibited the United States authorities from undertaking otherwise desirable monetary stabilisation policies, though neither was willing to advocate its outright abandonment.

But there was an important difference in emphasis between their views about what could be accomplished by monetary policy if it were not constrained by the gold standard. Viner, noting that "[f]or over a century writers have pleaded for the abandonment of the gold standard and the substitution of a managed paper currency. .." (1932, p. 35) expressed ". . .an individual view, [that] we know too little as yet of the possibilities of stabilization to take any major steps in that direction." (1932, p. 37) The most he would concede was that

"We could soon learn a great deal more than is known of the possibilities of comprehensive stabilisation, if some country now off the gold standard were to attempt by credit control or otherwise to raise its price level somewhat above its present level, and then were to regulate the volume of bank credit so as to approximate a constant level in some significant index of prices." (1932 p. 38)

Williams, on the other hand, was more confident:

"Granting. . the dangers of expecting too much from credit management, and granting also the deficiencies of our understanding, it is safe to say that both our ability to control and our knowledge of why to control considerably outrun our performance." (1932, p. 156) 
and he concluded that

"The immediate problem is to restore normal conditions. The greatest single help, internally, would be a vigorous open market policy designed to reduce rediscounts of member banks and to increase the supply of purchasing power. . . The logical end of the evolution of credit management, and the only real hope of solution of the conflict between external and internal stability, would be closer co-operation of central banks looking toward some form or degree of supernational management." (1932, p. 157)

The differences between Viner and Williams revealed here do not concern matters of theory, but rather of empirical judgement. Viner is skeptical but nevertheless open minded about what open market operations might achieve, while Williams is more confident, although that confidence is of relatively recent origin. The views he had expressed in (1931) had, as we have noted, been more cautious. 25

Is it going too far to see the influence of Hawtrey, and Currie too, on Williams' paper? Certainly, and as we have already seen, optimism about the power of open market operations is expressed in The Art of Central Banking (1932), and is the major factor distinguishing Hawtrey's attitude, one shared by Currie, from that of Charles Hardy (another author of the 1932 Manifesto) as set out in his own book of the same year. Furthermore, the phrase ". . .closer co-operation of central banks looking towards some form or degree of supernational management" provides an excellent summary of the aims of the 1922 Genoa Resolutions of which Hawtrey had been the principal architect. And the opening theoretical section of Williams' paper adopts Hawtrey's (1919) method of focussing on banking behaviour in the absence of currency in order to demonstrate propositions, also closely associated with Hawtrey, namely, ". . .that under central banking the control [of credit] can never be automatic [and that this] would seem to follow from the nature of the credit mechanism" (Williams, 1932, p. 135). The circumstantial evidence is strong, but the fact remains that Williams does not cite Hawtrey. This suggests that, if we are seeing Hawtrey's influence here, it was exercised indirectly, 
perhaps by way of Currie, or indeed by way of Keynes' Treatise. ... As Deutscher (1990) has shown, Hawtrey's contributions had left a considerable mark on this work, a mark acknowledged by Williams in his own (1931) review.

Even so, the only explicit mention of Hawtrey in the (1932) Harris Foundation volume is critical. It occurs in the course of Gottfried von Haberler's (1932) defense of Hayek's (1931) views, which, contrary to those of Hawtrey, were that expansionary, rather than contractionary, monetary policy had caused the depression in the first place and that expansionary policy, if implemented in 1932, would only serve to prolong it. Haberler was a visitor at Harvard that year, but he was not, needless to say, a signatory of the manifesto which emerged from the Harris Foundation conference, while Viner and Hardy, despite their reservations about what might be achieved by expansionary policy, had participated in drafting it. We should not, therefore, make too much of institutional affiliations at this point, nor should we overstress the extent of the differences of opinion between Williams and colleagues. But the facts remain that, if we follow Friedman in looking to the 1932 Harris Foundation conference for evidence of that "hopefulness" which he tells us marked the Chicago tradition, we shall find more of it in the contribution of Williams than anywhere else; and if we look further afield, we shall also find it in the work of Hawtrey -- by then published -- and Lauchlin Currie -- then in progress. ${ }^{26}$

Another important early record of Chicago analysis cited by Friedman, namely, the Appendix on "Banking and Business Cycles" attached to Simons et al. (1933) concisely and vigorously elaborates the view that

"In any money economy there will be some tendency toward cumulative maladjustment over periods of a few years, largely because of two circumstances: (a) The relative inflexibility of those prices which largely govern operating costs of production; and (b) the sensitiveness or responsiveness of money 'circulation' to changes of business earnings." (1933, Appendix, p. 1)

That input costs, and particularly money wages, were relatively inflexible had been a key 
proposition of quantity theoretic explanations of the cycle, particularly British explanations, since the work of Marshall and Marshall (1879), and it had been a standard feature of Hawtrey's analysis since 1913. And the "sensitiveness. . of money 'circulation' to changes of business earnings" is precisely what Hawtrey meant when he referred to the "inherent instability of credit." There is no way of knowing whether Hawtrey directly influenced this Chicago analysis, which lacks any references to the literature. ${ }^{27}$ However, as Hayek suggested to Friedman in a 1967 letter dealing with common intellectual influences on Keynes and Simons, and quoted in Friedman $(1967$, p. 88, fn. 7), "We all held similar ideas in the 1920 s. They had been most fully elaborated by R.G. Hawtrey who was all the time talking about the 'inherent instability of credit' but he was by no means the only one. ..". But if Hawtrey was "not the only one," he was beyond doubt the leading exponent of the style of monetary cycle analysis deployed by Simons and his colleagues. ${ }^{28}$

Simons et al. (1933) advocated 100 per cent money, and subjecting monetary policy to a legislated rule. They were somewhat more original in this normative analysis, but even here there are precedents in earlier literature. The 1918 Nobel laureate in chemistry Frederick Soddy wrote a number of unconventional works on economic matters during the 1920 s and 1930s, and advocated a 100 per cent money scheme in Wealth, Virtual Wealth and Debt (1926, pp. 197-199); at least one Chicagoan was familiar with this work, namely Frank H. Knight, who had reviewed it favourably in the Saturday Review of Literature. ${ }^{29}$ More generally, there had been widespread discussion in the United States of governing monetary policy by a legislated rule for nearly a decade: the Strong bills of 1926 and 1927 had sought to do just that with a price stabilization rule, and had been supported by such economists as Gustav Cassel, John Commons and Irving Fisher; and the Goldsborough Bill of 1932 had revived this idea. Constant money growth, which would later reappear in Friedman's work, had also been advocated as a 
suitable aim for monetary policy, with varying degrees of enthusiasm by Carl Snyder (1924) and Lionel Edie (1931), while the "neutral money principle" of stabilising money expenditures (MV in Fisherian terms), developed by the Austrian School in the late 1920s, had by 1932 become well enough known in the United States to attract the cautious support of Charles Hardy among others (See 1932, p. 324). ${ }^{30}$

But for all that, Simons et al. did make a unique and important contribution to quantity theoretic analysis. As Hart pointed out in his 1935 discussion of the "Chicago Plan," "The '100 per cent. system'. . [was] an effective remedy for the weaknesses of the banking system which now unfit it either for automatic functioning or for use as an instrument of monetary management" (1935, p. 444, italics added). Currie, to whose "masterly account" of the way in which ". . conversion of chequing deposits into cash or vice versa influences the total quantity of both in existence" Hart (1935, p. 442) paid tribute, very clearly advocated it for the latter purpose. As Currie had remarked in 1933

"In such a delicate and difficult task as the determination of proper central banking policy, it would appear to be a safe generalization that automatic rules render more difficult the task of central bankers, while discretionary powers facilitate it." (1933b, p. 356)

Paul Douglas also took such a view, listing among the advantages of 100 per cent. money that it would ". . provide complete social control over monetary matters. .." (1935, p. 187).

Not so Henry Simons for whom ". . .managed currency without definite, stable, legislative rules is one of the most dangerous forms of 'planning'" (1935, p. 558). The importance which Simons attached to this point may be gauged from the fact that, though this quotation is drawn from his review of Currie (1934b), almost the same phrases are to be found in Simons et.al. (1933, pp. 4-5), Simons (1934, p. 24) and Simons (1936, p. 339). Readers of Hart (1935) are given the impression that the "Chicago Plan" and "100 per cent. money" are one and the same thing, but the 1933 mimeo makes it quite clear that 100 per cent. money is but 
one component of a plan which also encompasses a legislated rule for the conduct of policy. Moreover, where Hardy had remarked, with reference to the debate about legislated monetary rules in 1926-27, that "The controversy over the stabilization issue hinges chiefly upon differences of economic theory. It does not involve party traditions or conflicting sectional or class interests." (1932, p. 202, italics in original), Simons in (1934) presented a monetary rule as an integral part of A Positive Program for Laissez-Faire. ${ }^{31}$ The originality of Simon's contribution to quantity theoretic analysis thus lay in linking that analysis to liberal political values. It was this, rather than any positive hypothesis or empirical judgement, that separated Chicago work from that of Hawtrey and those Harvard economists whom he influenced. ${ }^{32}$ Simons discussed a range of possible rules: "At one extreme is the rule of fixing the quantity $(M)$ or the total turnover $(M V)$; at the other is the rule of stabilizing some index of commodity prices." (1934, pp. 24-25), and the change in his position between 1933 and 1936 about which was best is worth some discussion. His first preference, in 1933, had been for fixing the quantity of money. Among the disadvantages of price level stabilization which he then found compelling was that

"It is sadly lacking in definiteness as a rule of long run management. Thus it leaves too much room for administrative discretion and political manipulation. (This will be clear immediately to anyone familiar with the technical. statistical problems of price level measurement over long periods). (Simons et. al. 1933, p. sup. 7)

A constant money supply rule was preferable because, among other things, it implied a balanced budget rule for fiscal policy too, and because it implied that input prices, and particularly wages, which Simons believed to be sticky in nominal terms would not have to move. ${ }^{33}$ It was even preferable to stabilising $M V$ - the neutral money principle - because of difficulties in establishing procedures for offsetting changes in $V$

". . .without in effect granting to the monetary authority large freedom for discretionary action[.] Moreover, if we be not alarmed by the thought of some 
discretionary action, is there any feasible way of permitting discretionary measures in the short-run and still assuring realization of the long run objectives?" (1933, p. sup. 4)

And in any event, ". . .some of us are inclined to feel that the disturbances occasioned merely by changes in velocity are unlikely to be of serious magnitude." (1933, p. sup. 3)

Friedman (1967) conjectured that Simons' (1936) advocacy of a price level rule was the result of ignorance of the monetary facts of the Great Depression, but Patinkin (1979) questioned this interpretation, arguing that by 1936, and as a reviewer of Currie's (1934b) book, Simons must have had a reasonable grasp of those facts, even if he himself was not deeply impressed by empirical work. The above evidence supports Patinkin's position, for it suggests that in 1933 Simons' empirical judgement was reasonably accurate. This is perhaps not surprising, because Currie's (1932) basic work documenting both the mild contraction of deposits of 1928-29, and what he called their "catastrophic decline" in 1931, the very facts which underlay his later (1934a \& b) critique of Federal Reserve policy, had already been published, while both Currie's (1933c) estimates of narrow money velocity and Angell's (1933) for broad money velocity appeared in November of that year.

What had come to concern Simons in 1936 , was not short run cyclical instability of velocity per se, based on a misreading of recent experience, but the potential for such instability to appear in the future as a consequence of the institutional change which the introduction of a rule might create. Modern readers will recognise what we nowadays call "the Lucas critique" or "Goodhart's Law" as underlying Simons' position, though he himself dealt only with one special case of what we now think of as a pervasive problem.

"The fixing of the quantity of circulating media might merely serve to increase the perverse variability in the amounts of 'near-moneys' and in the degree of their general acceptability, just as the restrictions on the issue of bank-notes presumably served to hasten the development of deposit (checking-account) banking." (1936, p. 341) 
This matter had earlier been discussed by Hart, who noted that "A repetition of the fiasco of bank note regulation -- which drove monetary transactions into the less manageable form of chequing on bank balances -- would be disastrous." (1935, p 451) Neither Hart nor Simons identified the specific historical experience which he had in mind here, but I conjecture that both were referring to Sir Robert Peel's Bank Charter Act of 1844, which failed to achieve its purpose because, among other weaknesses, it imposed $100 \%$ marginal reserve requirements against only Bank of England notes, leaving deposit banking essentially unregulated. They could, though, have been referring to the development of deposit banking among state chartered banks in the United States in response to the prohibitive taxation of their note issues instituted in $1863 .^{34}$

Whatever prompted Simons' shift from a money supply rule to a price level rule, however, two things are clear: it did represent for him a shift to a second-best position which opened up uncomfortably large scope for the exercise of discretionary power; but, even more important, he did think it nevertheless feasible to enforce a price stabilization rule, so that its legislation remained a far superior alternative to leaving government authority in the monetary area unfettered: as he put it, "If price level stabilization is a poor system, it is still from a liberal viewpoint, infinitely better than no system at all." (1936, p. 358) The link between a monetary approach to business cycle analysis and a liberal political agenda, that is to say, which I have suggested was the major distinguishing feature of the early "Chicago" tradition, remained firmly in place in 1936, as it would in the later work of Mints (1950) and Friedman.

\section{v. CONCLUDING COMMENTS}

1936 was of course a crucial year in the development of macroeconomics. The General Theory filled intellectual vacuums in a number of important places. Before then, the main rival to the quantity theoretic tradition discussed in this paper was Austrian business cycle theory, 
which taught that the only cure for the depression was to leave well alone and allow it to come to a natural end. As Friedman has plausibly suggested, this negative policy message did much to predispose economists exposed to it in institutions where it had replaced quantity theoretic analysis to embrace Keynesian ideas. ${ }^{35}$ Friedman is surely right also in claiming that, after 1936, Chicago was unique among major centres in preserving and developing further the quantity theoretic tradition of the 1920 s and 1930 s as the basis of an important body of ongoing work, and in suggesting that the failure of the Keynesian revolution immediately to overwhelm this centre had much to do with the dominance there of this tradition. ${ }^{36}$

It is beyond the scope of this paper to describe the subsequent development of Chicago thought, and to show how some of the theoretical innovations of the General Theory became incorporated into it. It will suffice here: to express agreement with Patinkin's (1969) judgement that Friedman's (1956) capital theoretic model of the demand for money betrays a deep and unmistakable Keynesian influence; to draw attention, nevertheless, to the essential similarity between Friedman's interpretation of the causes of the Great Depression and his views on what appropriate monetary policy could have accomplished between 1929 and 1933, and the positions taken by Hawtrey, Williams and Currie on the same questions; to note that advocacy of monetary rules as a central component of a broader liberal policy agenda is what gave Chicago work of the 1930s its distinctive character, and to conclude that it is only the latter feature which links what has come to be called "monetarism" to any tradition uniquely associated with the Chicago of the early 1930 s.

As I have argued in this paper, the positive elements in the Chicago monetary economics of those years were also to be found elsewhere, and in particular in the writings of Hawtrey and certain Harvard economists. They thus had exactly the same origins as did the positive macroeconomics of the "New Deal" to which Currie was a major contributor. In the light of 
this, and in the light of Hawtrey's well documented influence on the development of Keynes' own thought, is it so surprising that the Chicago tradition was in due course able to assimilate elements of Keynes' positive analysis while retaining the capacity to develop an alternative policy doctrine to conventional American "Keynesianism?" And now that the Monetarist controversy of the 1960s and 1970s is itself history, is it so surprising that its historians are finding one of its most striking features to lie in the amount of common analytic ground that the antagonists shared? On the interpretation offered here, "Monetarism" and "Keynesianism" were both rooted in the same quantity theoretic tradition, and differed only with respect to political values. 


\section{FOOTNOTES}

1. This paper is concerned with the origins of the Chicago tradition, rather than its later development. It has little to say about the post-1936 literature, and Warburton therefore plays no role in what follows.

2. Indeed, Fisher himself wrote of his work before 1932 in the following terms, "The vast field of 'business cycles' is one on which I had scarcely ever entered before, and I had never attempted to analyze it as a whole." (1932, p. vii) Before that date, Fisher's work on cycles had mainly been devoted to showing how variations in the rate of inflation were associated with fluctuations in various measures of real activity, and he had been an active supporter of legislating price stability as a goal for the Federal Reserve System. Thus he supported the Strong Bills of 1926-27, not to mention the Goldsborough Bill of 1932. Nevertheless, the question "Why not Fisher, rather than Hawtrey?" inevitably recurs throughout this paper.

3. It is generally acknowledged that Fisher's (1935) book was a development of the Chicago proposals, and in no sense an original contribution. There is no sign, for example, of the 100 per cent. money proposal in his writings of (1932) or (1933). Tobin's (1987) suggestion that Fisher had been developing the proposal since the mid 1920s seems to be without foundation. Perhaps Tobin had in mind Fisher's commitment to price level stability by way of a compensated dollar, which goes back, of course to (1911) and was written into the Goldsborough Bill, though it was deleted from the version of that bill passed by the House of Representatives but defeated in the Senate in 1932.

4. This information about Currie acting as Hawtrey's assistant is drawn from Roger Sandilands' (1990) recent, and important, biography of Currie. In a personal 
communication to the author (July 8 1992) Currie says that the work involved attending Hawtrey's graduate lectures and grading papers. He acted in a similar capacity for Schumpeter, and recalls getting little out of his lectures and disagreeing with his interpretation of the cycle as the result of waves of innovations. This letter also refers to the intention that Currie would become Young's assistant upon the latter's planned return to Harvard from the London School of Economics.

5. Patinkin (1969), and elsewhere, has rightly insisted that the phrase "quantity theory" at this time was almost universally understood to mean a proposition about a unidirectional and proportional effect running from the quantity of money to the general price level. The phrase should not, therefore, be used to characterise a theory of the business cycle, particularly one in which chains of causation running from money-income to money, as well as in the opposite direction, play a prominent role. In what follows, I shall from time to time, and with some trepidation, use the less specific phrase "quantity theoretic" to characterise such an approach. The qualifier "monetary" is too broad, since it can encompass the very different Austrian cycle theory of Friedrich von Hayek (1931, 1933) while "monetarist" is anachronistic, and conjures up stable demand for money and natural unemployment rate hypotheses that are not to be found in the literature dealt with here.

6. Thus the pervasive Fisherian influence on Hawtrey's quantity theoretic work was recognised by Young, but so was the fact that Hawtrey had carried many elements of Fisher's analysis a good deal further than its originator. On this matter, see also Angell (1926) pp. $182 \mathrm{ff}$. , where a discussion of Hawtrey's work based explicitly on Young's writing and teaching is to be found. The novelty of Hawtrey's work, not least in the way in which "The older machinery of quantities of money and goods and transactions, 
is. . put into the background" (1926, p. 283) is explicitly stressed by Angell. I am informed by Mark Blaug that Hawtrey's Currency and Credit still appeared on Angell's undergraduate reading lists in the early 1950 s.

7. Angell (1926, p. 182) also stresses this rather novel feature of Hawtrey's analysis. Note that it also appears, albeit without a direct reference to Hawtrey in Williams (1932). See below, pp. 000 .

8. Robertson (1915) had noted the originality and importance of this element in Hawtrey's analysis. It has no parallel in Fisher's work, where the currency deposit ratio is assumed to be stable except during and immediately after, rather than in advance of, the crisis phase of the cycle.

9. But it was not the position of Fisher (1932) whose "debt-deflation" hypothesis led him to accord an altogether more important role to the stock market crash. See (1932), pp. 85 ff.

10. And the only item in the above list which figures prominently in Fisher's writing before 1919 is the matter of a monetary rule, in the form of his proposals for a "compensated dollar."

11. And this was acknowledged by Mason (1982) in his history of the Harvard department, a history in which, it is sad to note, the name of Lauchlin Currie appears but once, with no reference to his work. Sandilands (1990) complains, with some justice, that Friedman and Schwartz $(1963,1970)$ paid insufficient attention to Currie's work, and in a recent letter to the author, Friedman acknowledges this with an explicit "mea culpa". Currie's neglect by the profession began earlier, however, and was comprehensive enough to verge on the scandalous. For example Mints gives but three grudging references to his work in (1945), and none in (1950) despite the fact that the latter book expounds a 
version of the monetary explanation of the depression pioneered by Currie (1934a, 1934b). Currie's name does not so much as appear in the 45 page bibliography of "Articles on Monetary Theory" prepared by Harlan Smith, with the "constant advice" of Lloyd Mints, and appended to the American Economic Association's (1952) Readings in Monetary Theory, a collection which was, for a good decade, the standard source of graduate student reading material in the area. Nor did Currie fare any better at the hands of Harvard economists. His name fails to appear in such products of that department as Hansen $(1941,1951)$ or Harris (ed.) (1945).' Karl Brunner's introduction to the (1968) reprint of Currie (1934b) is an honourable exception to all this, as was the inclusion by Harry G. Johnson and Albert Rees of Currie (1934a) in their selection of Landmarks in Political Economy from earlier issues of the JPE.

12. Schumpeter's contribution to this volume is something of an exception. It is at least coherent in its presentation of the Austrian view of the Depression, namely that it was the result of overinvestment, and that any attempt to use expansionary policy to mitigate it would only make matters worse.

13. I am indebted to Professor Charles Blitch for this information, who also tells me that the only record of the existence of this work is a complimentary reference to it in a 1927 letter from W. C. Mitchell to Young. Blitch speculates that Young's wide ranging curiosity, combined with the generosity with which he gave time to the work of others, would have made it difficult for him to complete a systematic treatise on a single topic. In recent years, Young's work on the role of increasing returns to scale has attracted attention among exponents of modern growth theory, and two relatively recent accounts of his life and works, Blitch (1983) and Newman (1987) have appeared. Neither of these cites Young's empirical work on the United States monetary system discussed 
below, and my attention was first drawn to it by Deutscher (1990) pp. 195-199.

14. The information about Young's association with the Federal Reserve Bank of New York is drawn from Blitch (1983).

15. It should be noted that an important study dealing with, among other things, the role of New York banks in holding reserves for the National Banking system, the unsuitability of call loans to Wall Street as secondary reserves for the system as a whole, and the desirability of creating a central bank to act as a lender of last resort, had been carried out for the National Monetary Commission by another Harvard economist Oliver Sprague (1910). Young also referred to this work in (1928). The reader is reminded that the 1907 crisis, the last of those described by Sprague, helped provide the impetus for Hawtrey's first book, Good and Bad Trade (1913), and that a well informed discussion of the National Banking System appears in that book, pp. $169 \mathrm{ff}$.

16. The reference here is to the first (Congressman James) Strong bill, on which hearings were held in 1926-27. Charles Hardy (1932) Chapter X gives an excellent account, from a contemporary standpoint, of the intellectual background to these hearings.

17. Angell (1936) subsequently published data that appeared to show that ".. .outside currency and circulating [i.e., chequable] deposits alike tend to move with or after, but apparently never before. . .indices of production, trade and the like. .." but he was careful to note that "The conclusion cannot fairly be drawn from this, however, that the quantity of money is a purely passive factor in business activity." (1936, p. 60). His series differed from Currie's as a result of his using a different statistical technique to allocate unclassified non-member bank deposits between demand and time deposits, and Currie (1936) argued that his own method was more reliable. Moreover, Warburton (1946, reprinted 1966, p. 82), was later to argue, with specific reference to the 1927- 
1932 period that this description of the timing of variations was "contrary to his [Angell's] data." Nevertheless, the fact remains that Angell, who was a Ph.D. student of Young and Taussig took a rather pessimistic position on the power of monetary policy -- more akin to that which Currie (1934b, p. 116) attributed to Taussig (and to Mitchell) than to Currie's own position. Note that Friedman (1967) does not attribute to Simons a monetary explanation of the onset of the Depression and indeed it is hard to decide, from Simons writings, just what he thought about this matter. Friedman (1974) was later to cite Viner (1932. 1933), not Simons, as the Chicago economist who had anticipated his own views on the Depression. See however, the discussion on pp. 0000, below.

18. Hardy was at this time at the Brooking Institution, but he had been an instructor at Chicago between 1916 and 1922, where his students had included Mints and Simons. It is presumably this association which caused Friedman (1974) p. 164, fn. 19) to refer to him as a "Chicagoan at one remove."

19. I refer here to "one version" of this plan, because a variety of plans were "in the air" as well as in print in the early 1930s. Hart (1935) is an excellent source of information about the main alternatives discussed. Though Currie was to submit a detailed proposal for such a scheme to the then Secretary of the Treasury, Henry Morgenthau in September 1934 (see pp. 195 et. seq. of the 1968 reprint of Currie 1934b), earlier in the year he had thought that ".. it [could] hardly be regarded as practicable at the present time" (1934b p. 157) Hence the final three chapters of his book were devoted to proposals for modifying the then existing system. These included replacing the extremely cumbersome decision making process within the Federal Reserve system with a small board of ". . not more than three of four members," the introduction of uniform 
reserve requirements, along with the obligation of all banks emitting demand deposits to be members of the system, the abolition of the rediscounting privilege and the introduction of nationwide branch banking. The effectiveness of these measures, Currie well understood, would depend upon ". . .a radical change. . in the whole attitude toward banking at present held by the reserve administration." He specifically referred to the administration's commitment to the erroneous "commercial loan" theory of banking at this point, and noted that "It is. . .useless to increase the administration's control over money if what it is really trying to do is to control the quantity of bank assets." (1934b, p. 157)

It should also be pointed out, as Steindl (1991) has shown, that even in (1934b) there is a certain ambiguity in Currie's views about the extent to which the banking system's demand for free reserves was an active or a passive factor in the determination of the money supply. His inclination to the latter view became stronger as the 1930s progressed and the volume of free reserves continued to grow. Again as Steindl stresses, Currie's explanation of the 1938 downturn did not anticipate that of Friedman and Schwartz in attributing it to increases in required reserve ratios. Rather he blamed a tightening of fiscal policy. Indeed, in 1936 Currie advocated increasing required reserve ratios to mop up excess reserves. However, there is no evidence to support the view that Currie's beliefs about what the Federal Reserve System could have accomplished in 1930-32, had it acted soon and vigorously enough, changed as the 1930s progressed.

20. Patinkin (1971) has noted the lack of interest in empirical work of Mints and Simons, which differentiates the contributions so strongly from Friedman's. It is beyond the scope of the paper to investigate the origins of Friedman's empiricism. As I have suggested above, Young's empiricism, and that of his students, among whom Angell 
should be explicitly included in this context, presumably comes from his training in the American Institutionalist tradition at the University of Wisconsin. But of course Fisher (1911) had made extensive studies of U.S. monetary data, and in the 1920s, so did Carl Snyder, who was much influenced by Fisher. Snyder was on the staff of the Federal Reserve Bank of New York, to which Young acted as a consultant. Given the absence of formal statistical analysis from Hawtrey's work, it is in this regard rather than any other that the case for a Fisherian influence on the Harvard economists might be easiest to make. Against this, it should be noted that, unlike Snyder, both Angell (1933) and Currie (1933b) adopted income (or circuit, in Angell's terminology) velocity as opposed to Fisher's transactions velocity as a foundation for their empirical work. Angell (1926) chs. VII and XIII show that he was completely familiar with the British as well as Austrian origins of this concept. Note also that the third (1927) edition of Hawtrey's Currency and Credit contains a sharp critique of the concept of transactions velocity.

21. In a personal communication to the author of July 81992 , Currie notes that his relation with Chicago was through Viner, who occasionally lectured at Harvard. The earliest letters between Currie and Viner in Viner's papers date from November 1932 and refer to lectures delivered by Viner at Harvard a little earlier that autumn. Viner's letter to Patinkin of January 15 1970, reprinted in Patinkin (1981, pp. 267-268), in which there occurs the phrase "When I went to the Treasury in 1934, I encountered Lauchlin Currie.

. ." ought not, therefore, to be interpreted as indicating that this was Viner's first encounter with Currie. However, apart from the above-mentioned exchange of letters between the two in 1932, the correspondence between Currie and Viner that now survives all dates from 1935 and later. 
22. Rogers gave no lecture at the conference, but did take part in a round-table. Douglas' reference is to the mimeographed proceedings of the conference, rather than the published lectures, and though Rogers was not a signatory of the manifesto, the views it expresses are quite compatible with his own comments at the winter 1931 meetings of the Econometric Society: "Under present distressing conditions, easy money [by which he meant a low discount rate] is of little importance. Plentiful money would probably bring effective relief" Rogers (1933, p. 70). Rogers was a former student of Fisher, and Sterling Professor at Yale. These facts, along with Fisher's membership of the committee that drafted the Manifesto, provide the strongest evidence of which I am aware of a direct Fisherian influence on Chicago thinking. For an account of the monetary analysis developed by Yale economists during this period, notably Fisher, Rogers, and Harry Gunnison Brown, see Steindl (1992).

23. See Davis (1971, p. 129) for this information about the makeup of the drafting committee.

24. In his personal communication to this author of July 91992 , Currie remarks that the fact that he had been kept on at Harvard in anticipation of his acting as an assistant to Young upon the latter's expected return affected his relationship with Williams. Though they were personally friendly, Williams never regarded himself as Currie's "patron," and Currie did not attend the lectures in the course in which he acted as assistant. Indeed Currie goes so far as to remark that "I probably had more influence on his thinking than he on mine." This judgement, similar to that which many Ph.D. students make about their interaction with supervisors, is nevertheless quite consistent with the published record. 
25. Friedman also refers to Viner's (1933) Minnesota lecture, and the views Viner there expresses are more optimistic about the powers of monetary policy to alleviate the Depression than those he had set out in early 1932 -- but this paper was written about a year after the Harris foundation conference and, as Friedman notes, Viner was still inhibited at that time from recommending vigourous expansion in the United States by the difficulties he believed to be imposed by the maintenance of the gold standard-which was of course abandoned only a few months later.

26. The reader is, nevertheless, reminded of Douglas' reference to Rogers' informal contribution to this conference, and the written record of the latter's position as expressed in Rogers (1933).

27. But we may be reasonably confident that Irving Fisher did not. The last sentence of this Appendix states "It follows as a corollary, incidentally, that the problem of unemployment is not, to an important extent, a problem of debt." (Simons et. al. 1933, p. app. 6) To my eye, this reads like a direct repudiation of Fisher's "Debt Deflation Theory of Great Depressions" as set out in Fisher $(1932,1933)$, and probably as discussed at the 1932 Harris Foundation conference too.

28. But it was disingenuous of Hayek to try to associate himself with Hawtrey's quantity theoretic analysis. He had been, in the 1920s and 1930s, the outstanding exponent of the very different "Austrian" theory and he had then also been highly critical of quantity theoretic analysis. Austrian analysis led to an extremely pessimistic, indeed, nihilistic view of the scope for fighting the Depression with any sort of policy, either monetary or fiscal. Friedman refers explicitly to this style of theory as representing "the atrophied and rigid caricature [of the quantity theory] that is so frequently described by proponents of the income-expenditure approach. .." (1974, p. 163, square brackets and the phrase 
enclosed in them in original). There are two difficulties with Friedman's comments on this matter. First, the Austrian approach was explicitly offered by its exponents as an alternative, theoretically superior, doctrine to anything associated with the quantity theory; and second, Friedman correctly identifies von Mises and Robbins as among its exponents but fails to mention even the name of the leading figure in this group, namely von Hayek (See 1931, 1933). On Hayek's analysis, see Laidler (1992).

29. On this matter, see Daley (1980).

30. The policy nihilism of the Austrians was not shared by Hardy, but he was skeptical about how much of the Depression should really be blamed on monetary policy, and how much could be expected of it by way of a cure. Even so, as his participation in drafting the 1932 Harris Foundation manifesto attests, he still thought that the experiment of expansionary open market operations was worth trying.

31. And much of the rest of the program was concerned with eliminating the various monopolies which, in Simon's view, were responsible for the cost rigidities that had made the Depression so severe. It is worth noting that Simons was explicitly opposed to nationwide branch banking of the type favoured by Currie, because of his general aversion to business concentration.

32. To say this, of course, is also to say that Jacob Viner should not be categorised as a member of the Chicago School, a judgement with which, one suspects, he would not have been entirely unhappy. See Viner's letter to Patinkin of November 241969 , reprinted in Patinkin (1981), pp. 265-266.

33. Though Simons did see the need for a period of transition, involving reflation, before the constant money supply rule was to be enforced.

34. Hart (1935, p. 438, fn. 3) explicitly discusses the similarities and differences between the Chicago Plan and Peel's Act, but does not refer to American experience. Among the 
Chicago department, Viner would have been well enough aware of this episode to see its potential relevance, and draw his colleagues' attention to it; we also know from Hart's paper that Viner commented on the "Chicago Plan," though the explicit reference to him does not concern this point (See Hart 1935, p. 545, fn. 30). However, Viner's Studies in the Theory of International Trade, with specific reference to the provisions of Peel's Act, draws attention to ". . .changes in the ratio between bank notes and deposits and in their relative velocities. . .which the regulation of one type of means of payment might itself tend to bring about." (1937, p. 253)

35. That is surely why, in Britain, not just Cambridge economists, but many at the London School of Economics too, quickly took up the new doctrine. Austrian nihilism had made inroads at Harvard as well, where the combined effects of the death of Young, the departure of Currie and, perhaps also, Williams' accession in 1937 to a senior administrative position, ensured that a once vigorous tradition in quantity theoretic analysis had died out. There too, the triumph of Keynesian thought after 1936 was quick and close to complete. In Currie's case, of course, the economics of the New Deal which he did so much to create once in Washington easily assimilated Keynes' (1936) analysis, and came to be called simply, but unfairly to its American creators, Keynesian economics. On the American roots of the Economics of New Deal fiscal policy, including those nurtured at Chicago, particularly by Schultz, Viner and Douglas, see Davis (1971).

36. Which is not to say that particular individuals in other places did not continue to work in the tradition discussed in this paper. James Rogers' death in 1939 seems to have cut short further developments at Yale, but Angell at Columbia, Marget $(1938,1942)$ at Minnesota, (who was also, incidentally, a student of Young's, and a signatory of the 
1932 Harris Foundation conference manifesto) not to mention Warburton at the FDIC, all continued to work in the older tradition. 


\section{REFERENCES}

Angell, J.W. (1926), The Theory of International Prices, Cambridge, MA: Harvard University Press.

(1933), "Money, Prices, and Production: Some Fundamental Concepts," Quarterly Journal of Economics 48 (November), pp. 39-76.

(1936), The Behavior of Money, New York: McGraw Hill, reprinted New York: A. Kelley, 1969.

Blitch, C.P. (1983), "Allyn A. Young: A Curious Case of Professional Neglect," History of Political Economy 15, pp. 1-13.

Brown, D.V. et al. (1934), The Economics of the Recovery Program, Cambridge, MA: Harvard University Press.

Brunner, K. (1968), "Introduction" to Currie L. (1934b).

Currie, L. (1931a), Bank Assets and Banking Theory (unpublished Ph.D. thesis, Harvard University).

(1931b), "Review of Harold L. Reed: Federal Reserve Policy 1921-1930," American Economic Review 21 (March), pp. 162-164.

(1932), "Member Bank Indebtedness and Net Demand Deposits in the Federal Reserve System," Quarterly Journal of Economics 46 (May), pp. 509-525.

(1933a), "The Treatment of Credit in Contemporary Monetary Theory," Journal of Political Economy 41 (February), pp. 145-177.

(1933b), "Member Bank Reserves and Bank Debits," Quarterly Journal of Economics 47 (February), pp. 349-356.

(1933c), "Money, Gold and Income in the United States 1921-32," Quarterly Journal of Economics 48 (November), pp. 77-95.

(1934a), "The Failure of Monetary Policy to Prevent the Depression of 1929-32," Journal of Political Economy 42 (April), pp. 145-177.

(1934b), The Supply and Control of Money in the United States, Cambridge, MA,: Harvard University Press (reprinted with an introduction by Karl Brunner, and other additions, New York, Russell \& Russell, 1968).

(1936), "Review of James W. Angell: "The Behavior of Money: Exploratory Studies," American Economic Review 26 (December), pp. 789-791. 
Daley, H.E. (1980), "The Economic Thought of Frederick Soddy," History of Political Economy 12 (Winter), pp. 469-488.

Davis, J.R. (1971), The New Economics and the Old Economists, Ames Iowa: Iowa State University Press.

Deutscher, P. (1990), R.G. Hawtrey and the Development of Macroeconomics, London: Macmillan.

Douglas, P.H. (1935), Controlling Depressions, New York: W.W. Norton \& Co.

Edie, L.D. (1931), The Banks and Prosperity, New York.

Ely, R.T. (1916, 1923), Outline of Economics (revised editions, prepared by T.S. Adams, M. Lorenz, and Allyn A. Young) New York: Macmillan.

Fisher, I. (1911), The Purchasing Power of Money, New York: Macmillan. (1923), "The Business Cycle Largely a 'Dance of the Dollar'," Journal of the American Statistical Association 18 (December), pp. 1024-1028.

(1932), Booms and Depressions, New York: Adelphi.

(1933), "The Debt Deflation Theory of Great Depressions," Econometrica 1, pp. 337-357.

(1935), 100 per cent. Money, New York: Adelphi.

Friedman, M. (1956), "The Quantity Theory of Money, a Restatement," reprinted in Friedman (1969). (1969).

(1967), "The Monetary Theory and Policy of Henry Simons," reprinted in Friedman (1969), The Optimum Quantity of Money, London: Macmillan.

(1974), "Comments on the Critics," in Gordon, R.G. (ed.), Milton Friedman's Monetary Framework, Chicago: University of Chicago Press.

\& A.J. Schwartz (1963), A Monetary History of the United States 1862-1960, Princeton, NJ: Princeton University Press for the NBER.

(1970), The Monetary Statistics of the United States, Princeton, NJ: Princeton University Press for the NBER.

Haberler, G. von (1932), "Money and the Business Cycle," in Wright, Q. (ed.), (1932). 
(1937), Prosperity and Depression, Geneva: League of Nations.

Hansen, A.H. (1941), Fiscal Policy and Business Cycles, New York: W.W. Norton \& Co. (1951), Business Cycles and National Income, New York: W.W. Norton \& Co.

Hardy, C.O. (1932), Credit Policies of the Federal Reserve System, Washington, DC: The Brookings Institution.

Harris, S.E. (ed.) (1945), Economic Reconstruction, New York: McGraw Hill.

Hart, A.G. (1935), "The 'Chicago Plan' of Banking Reform," Review of Economic Studies (reprinted in AEA, Readings in Monetary Theory, London: Allen \& Unwin, 1952).

Hawtrey, R.G. (1913), Good and Bad Trade, London: Constable (reprinted, with a new foreword by the author, New York: A. Kelley, 1962). ed. 1927).

(1919), Currency and Credit, London: Longmans Green \& Co. (2nd ed. 1923, 3rd (1932), The Art of Central Banking, London: Longmans Green \& Co.

Hayek, F.A. von (1931), Prices and Production, London: Routledge. (1933), Monetary Theory and the Trade Cycle, London: Routledge and Kegan Paul.

Humphrey, T.M. (1971), "Role of Non-Chicago Economists in the Evolution of the Quantity Theory of Money," Southern Economic Journal 38 (July), pp. 12-18.

Keynes, J.M. (1930), A Treatise on Money (2 Vols.), London: Macmillan. (1936), The General Theory of Employment, Interest and Money, London: Macmillan.

Laidler, D. (1991), The Golden Age of the Quantity Theory, Hemel Hempstead: Philip Allan, Princeton, NJ: Princeton University Press. (1992), "Hayek on Neutral Money and the Cycle," London, ON, University of Western Ontario (mimeo).

Marget, A. (1938,1942), The Theory of Prices (2 Vols.), New York: Prentice Hall.

Marshall, A. and M.P. Marshall (1879), The Economics of Industry, London: Macmillan.

Mason, E. (1982), "The Harvard Department of Economics from the Beginning to World War II," Quarterly Journal of Economics 97, pp. 383-433. 
Mints, L.W. (1945), History of Banking Theory, Chicago: University of Chicago Press. (1990), Monetary Policy for a Competitive Society, New York: McGraw-Hill.

Morgenstern, O. (1929), "A.A. Young" (reprinted in Schotter A (ed.) Selected Economic Writings of Oskar Morgenstern, New York: New York University Press, 1976).

Newman, P. (1987), "Allyn A. Young," in Eatwell J., Milgate M. and Newman P. (eds.), The New Palgrave: a Dictionary of Economics, London: Macmillan.

Patinkin, D. (1969), "The Chicago Tradition, the Quantity Theory, and Friedman," Journal of Money, Credit and Banking, reprinted in Patinkin (1981).

(1973), "More on the Chicago Monetary Tradition," Southern Economic Journal, reprinted in Patinkin (1981).

(1979), "Keynes and Chicago," Journal of Law and Economics, reprinted in Patinkin (1981). Press.

Robertson, D.H. (1915), A Study of Industrial Fluctuations, London: P.S. King.

Rogers, J.H. (1933), "The Absorption of Bank Credit," Econometrica 1 (January), pp. 63-70.

Sandilands, R. (1990), The Life and Political Economy of Lauchlin Currie, Durham, NC: Duke University Press.

(ed.) (1990), "Nicholas Kaldor's Notes on Allyn Young's LSE Lectures 1927-29," Journal of Economic Studies 17, No. 3/4, pp. 2-114.

Schumpeter, J.A. (1954), History of Economic Analysis, New York: Oxford University Press.

Simons, H.C. (1934), A Positive Program for Laissez-Faire: Some Proposals for a Liberal Economic Policy, Public Policy Pamphlet \#15, H.D. Gideonse (ed.), Chicago: University of Chicago Press.

(1935), "Review of L. Currie's The Supply and Control of Money in the United States," Journal of Political Economy 43 (April), pp. 555-558.

(1936), "Rules Versus Authorities in Monetary Policy," Journal of Political Economy (reprinted in AEA Readings in Monetary Theory, London: Allen \& Unwin 1952). 
et al. (1933), "Banking and Currency Reform, including Appendix entitled Banking and Business Cycles, and Supplementary Memorandum on Long-term Objectives of Monetary Policy," Chicago, University of Chicago (unsigned mimeo).

Snyder, C. (1924), "New Measures in the Equation of Exchange," American Economic Review 14 (December), pp. 699-713.

Soddy, F. (1926), Wealth, Virtual Wealth and Debt, New York: E.P. Dutton \& Co.

Sprague, O.W. (1910), A History of Crises under the National Banking System, Washington, DC: Government Printing Office.

Steindl, F.G. (1991), "The Monetary Economics of Lauchlin Currie," Journal of Monetary Economics 27 (June), 445-462.

(1992), "Yale and the Monetary Interpretation of the Great Depression," Oklahoma State University, mimeo.

Tobin, J. (1987), "Irving Fisher" in Eatwell J., Milgate M., and Newman P. (eds.), The New Palgrave: a Dictionary of Economics, London: Macmillan.

Viner, J. (1932), "International Aspects of the Gold Standard," in Wright, Q. (ed.), (1932). (1933), Balanced Deflation, Inflation or More Depression?, Minneapolis: University of Minnesota Press. (1937), Studies in the Theory of International Trade, New York: Harper \& Bros.

Warburton, C. (1966), Depression, Inflation, and Monetary Policy: Selected Papers 1945-53, Baltimore, MD: Johns Hopkins University Press.

Wicksell, K. (1898), Interest and Prices (tr. R.H. Kahn, London: Macmillan, for the Royal Economic Society, 1936).

Williams, J.H. (1931), "The Monetary Doctrines of J.M. Keynes," Quarterly Journal of Economics 45 (August), 547-587.

(1932), "Monetary Stability and the Gold Standard," in Wright, Q. (ed.), (1932).

Wright, Q. (ed.) (1932), Gold and Monetary Stabilization: Lectures on the Harris Foundation, Chicago: University of Chicago Press.

Young, A.A. (1919-20), "Review of R.G. Hawtrey's Currency and Credit and I. Fisher's Stabilizing the Dollar," Quarterly Journal of Economics 34, pp. 520-532. (1924), "Review of R.G. Hawtrey's Currency and Credit (2nd ed.) and Monetary Reconstruction," American Economic Review 14 (June), pp. 349-351. 
(1927), Economic Problems New and Old, Cambridge, MA: The Riverside Press. (1928), An Analysis of Banking Statistics for the United States, Cambridge, MA: Harvard University Press. 